\title{
KERAKATAN AND BAPARCAYAAN IN DIAMOND TRANSACTIONS THROUGH PENGEMPIT (THE ANTHROPOLOGY OF ISLAMIC LAW STUDY)
}

\author{
Amelia Rahmaniah \\ Sharia Faculty of Universitas Islam Negeri Antasari \\ Jalan Ahmad Yani, Km 4.5 Banjarmasin, Kalimantan Selatan, Indonesia \\ e-mail: ameliarahmaniah@uin-antasari.ac.id \\ Syamsul Anwar \\ Sharia and Law Faculty of Universitas Islam Negeri Sunan Kalijaga \\ Jalan Laksda Adisucipto, Kabupaten Sleman, Daerah Istimewa Yogyakarta \\ e-mail: hsyamsul.anwar@uin-suka.ac.id \\ Rahmani Timorita Yulianti \\ Islamic Law Faculty of Universitas Islam Indonesia \\ Jalan Kaliurang St No.Km. 14,5, Krawitan, Daerah Istimewa Yogyakarta \\ e-mail: rahmanitimorita@uii.ac.id
}

\begin{abstract}
Abstrak: Penelitian terhadap budaya kerakatan dan baparcayaan dalam transaksi jual beli intan melalui pengempit ini dilatarbelakangi oleh keinginan untuk menggambarkan budaya kerakatan dan baparcayaan tersebut beserta maknanya karena aktivitas transaksi jual beli intan melalui pengempit ini bagi kebanyakan orang hanya merupakan aktivitas biasa. Akan tetapi sebenarnya ia merupakan budaya yang mempunyai makna jauh lebih kompleks dari pada yang diperkirakan bahkan oleh pemilik budaya sendiri, sehingga penelitian ini akan menjadikan makna budaya dapat dipahami dan dapat menjadi contoh positif bagi masyarakat lainnya. Penelitian ini adalah penelitian antropologi hukum Islam dengan pendekatan antropologi hukum. Data dalam penelitian ini diperoleh dari wawancara mendalam (indepht interview) mengenai pengalaman informan (individual's life history). Temuan dalam penelitian ini menunjukkan bahwa budaya kerakatan dan baparcayaan yang terdapat dalam transaksi jual beli intan melalui pengempit adalah hukum yang hidup dalam masyarakat. Budaya tersebut merupakan pengejawantahan nilai-nilai hukum Islam dalam ruang sosial konkret dan dimotivasi oleh iman kepada Allah swt. Budaya kerakatan dapat dilihat dari perilaku sesama pengempit yang saling membantu bila terjadi musibah, saling memberi bila intannya laku terjual, dan saling memberi informasi mengenai pembeli dan mengenai intannya. Sedangkan budaya baparcayaan dapat dilihat dari perilaku antara pemilik intan dengan pengempit yang tidak membuat perjanjian tertulis tetapi hanya secara lisan saja. Budaya kerakatan dan baparcayaan ini mempunyai makna religius, ekonomi, dan sosial. Budaya kerakatan dan baparcayaan ini merefleksikan platform religius-syar'i yang kuat bagi kehidupan ekonomi dan sosial masyarakat Banjar.
\end{abstract}

Kata Kunci: budaya, kerakatan, baparcayaan, intan, pengempit 


\begin{abstract}
Research on kerakatan and baparcayaan culture in diamond transactions through pengempit was motivated by the aim to describe the culture of kerakatan (solidarity) and baparcayaan (trust). They were not only ordinary activities but also cultures that had far more complex meaning than what was predicted. This research made cultural meaning could be understood and became a positive example for people. This research was categorized within the anthropology of Islamic law studies using a legal anthropological approach. The data in this study were obtained from in-depth interviews about the informants' experiences. The findings of this study were the culture of kerakatan and baparcayaan in the transactions of diamonds through pengempit was a law in society. Those two cultures were the manifestation of Islamic law values in a concrete social space which motivated by the faith in Allah. The culture of kerakatan could be seen from the behavior of pengempit who helped each other in disasters, gave money to each other if the diamonds were sold, and gave information to each other about buyers and diamonds. The culture of baparcayaan could be seen from the behavior between diamond owners and pengempit who only made verbal not written agreements. Kerakatan and baparcayaan culture had religious, economic, and social meanings. Kerakatan and baparcayaan culture reflected a strong religiousshar'i for the economic and social life of the Banjar people.
\end{abstract}

Keywords: culture, kerakatan, baparcayaan, diamond, pengempit

\section{INTRODUCTION}

A diamond is a precious gemstone. It was discovered for the first time in India in $8 \mathrm{BC}$, and for the second time in Kalimantan in 800 AD. Diamonds in Kalimantan had been known in the 2nd century, then in the 18th century which exactly in 1727 AD diamonds were discovered in Brazil. In the 19th century (1866), they were found in South Africa, and other countries such as China, Siberia, Africa, and Australia. ${ }^{1}$

The trade of diamonds in Kalimantan had been famous since 1604. It was proved by the number of diamond exports from Kalimantan in 1738 which reached 8-12 million guilders, a very large number at that time. Since 1400, Chinese traders had targeted South Kalimantan because it was a center of diamond trading. Until the 15th century, Tanjung Pura and Matan in South Kalimantan were the centers of diamond trading which was generally controlled by the Chinese. Even when the Portuguese came to the archipelago, they could not change the Chinese existing positions. ${ }^{2}$

The discovery, the creation, and the distribution of diamonds in South

\footnotetext{
1Said Aziz, "Potensi Endapan Intan Plaser di Lepas Pantai Kalimantan Selatan dan Barat," http://inaquarter.com, 28 Januari 2010, p. 1.
}

\footnotetext{
2 M. Suriansyah Ideham, Sejarah Banjar (Banjarmasin: Badan Penelitian dan Pengembangan Daerah Provinsi Kalimantan Selatan, 2003), p. 51.
} 
Kalimantan, especially Martapura, had convinced the world that South Kalimantan was one of the world's diamond producers. The image of Martapura as a city of diamonds was getting stronger by making this city a tourist destination for precious stone products, especially diamonds. The government of Martapura, in the mid1990s, established a gem shopping center called Cabaya Bumi Selamat (CBS). In this shopping center, various kinds of gemstones, especially diamonds and jewelry accessories were sold to consumers. ${ }^{3}$

In addition to $C B S$ in Martapura, there was also a market for selling diamonds inside Batuah traditional market located behind CBS. Different from CBS, this market traded unpolished-diamonds and polished-diamonds but not in the form of jewelry. In this market, the transactions were not between traders and last users, but were only between diamond traders like pengempit, small traders, and medium-sized traders. They traded diamonds obtained by pengepul to small and medium-sized traders or from diamond owners to their fellows.

${ }^{3}$ Yusuf Hidayat, "Praktik Pedagang Intan: Akses dan Pendayagunaan Kapital dalam Perdagangan Intan di Martapura, Kalimantan Selatan," Dissertation (Yogyakarta: the University of Gajah Mada, 2015), p 1.

${ }^{4}$ Hidayat, p. 2.
The small diamonds were sold by the diamond traders to shop owners at CBS, while the medium and large diamonds were sold to national and international markets. ${ }^{4}$ The trade of diamonds had characteristics including fluctuating and speculative prices because of many aspects that must be considered in determining the price of diamonds as such as the color, clarity, cutting, and carat or known as the Four 'C of Diamond (Color, Clarity, Cutting and Carat). Therefore, traders must be equipped with diamond analysis skills by focusing on those four aspects. ${ }^{5}$ Moreover, beyond a diamond there was a belief in society from ancient times, which assuming that diamonds were "supernatural beings" which referred to as "galub", it must be treated carefully.

Nowadays in Martapura, the transactions of diamonds were done through shops and pengempit (mediator). The transactions of diamonds through a pengempit had been done since ancient times because the majority of diamond trading was only hand to hand. ${ }^{6}$ The term pengempitan was mostly used since ancient times which means borrowing. Another

${ }^{5}$ Hidayat, p. 4.

'Interview with Abdul Gawi Hasan in Martapura, on July 26 ${ }^{\text {th }}$ 2013; in Amelia Rahmaniah, Dinamika Akad dalam Transaksi Jual Beli Intan di Martapura Kalimantan Selatan, ed. 1 (Yogyakarta: Total Media, 2015), p. 60. 
term used was pembelantikan, but this term was rarely used. ${ }^{7}$

There was some uniqueness of the diamond transactions through pengempit. First uniqueness was the activity of sharing information about the buyers and the diamonds among pengempit. Another uniqueness was that the transactions between pengempit and the diamond owners were done verbally without any written agreement, even though the diamonds were very valuable. ${ }^{8}$ This kind of behavior indicated a culture of kerakatan and baparcayaan in diamonds transactions through pengempit.

The activity of diamond transactions through pengempit for most people was just an ordinary activity, but in fact it was a complex meaningful culture even for the culture owners themselves. For this reason, this study aimed to describe the culture of kerakatan and baparcayaan along with the cultural meaning according to the owner of the culture and Islam, so that this research would make cultural meaning understandable and become a positive example for other communities.

\footnotetext{
${ }^{7}$ Interview with Husaini in Martapura, on Mei $25^{\text {th }}$, 2017.

${ }^{8}$ Interview with Abdul Gawi Hasan in Martapura, on July 26 $6^{\text {th }}, 2013$.
}

\section{METHOD}

This research was field research of descriptive Islamic law research 9 conducted on diamond owners and pengempit in Martapura, South Kalimantan. The approach of this research was the legal anthropological approach ${ }^{10}$ with an emphasis on community attitudes which indicated the existence of legal norms based on Islamic values and their meanings.

This research analyzed a normative ideal form of Islam as a reference for all Muslims. It could be said that this research was an anthropological study of Islamic law with the following characteristics: First, the anthropology of Islamic law examined human behavior which indicated the existence of legal norms influenced by Islamic values; Second, the anthropology of Islamic law examined human behavior as a model of reality which then related this model to Islamic law as a model for reality, so the changes could be seen from the ideal form; Third, the anthropology of Islamic law examined the meaning of human behavior based on the emic approach in the anthropological literature and also gave the

\footnotetext{
${ }^{9}$ Syamsul Anwar, Pemikiran Usul Fikih al-Gazzälī (450-505/1058-1111), Ed. 1 (Yogyakarta: Suara Muhammadiyah, 2015), p. 284.

10 Hilman Hadikusuma, Pengantar Antropologi Hukum, Cet. 2 (Bandung: PT. Citra Aditya Bakti, 2004), p. 4.
} 
meaning of that behavior based on the Islamic perspective; Fourth, the anthropology of Islamic law contributed to the development of Islamic legal studies.

There were four informants in this study who were selected based on their knowledge or experience of the phenomenon under study (purposive sampling technique). In the beginning, the number of informants in this study was not specifically determined, but the searching process for informants was stopped when the researcher found similar information among informants. Data collection in this study was carried out through in-depth interviews with informants regarding their experiences, which in cultural anthropology was called an individual's life history.

\section{RESULTS AND DISCUSSION}

1. The Role of Pengempit in Diamond Transactions

The transactions of diamonds in Martapura were done in stores and through a pengempit. The transactions through pengempit had been done since ancient times because the majority of diamond trading was only hand to hand. ${ }^{11}$ A long

\footnotetext{
${ }^{11}$ Interview with Abdul Gawi Hasan in Martapura, on July 26 $6^{\text {th }}$ 2013; in Amelia Rahmaniah, Dinamika Akad dalam Transaksi Jual Beli Intan di Martapura Kalimantan Selatan, Ed. 1 (Yogyakarta: Total Media, 2015), p. 60.
}

time ago, people sold diamonds traditionally (not in stores), they only sold outside the stores, while the stores only sold gold (gold stores). At that time, pengempit was only a person who understood diamonds because if he did not understand diamonds they would easily be tricked by others. Consequently, pengempit was only for professional, a person who did not understand diamonds could not become pengempit. ${ }^{12}$

In the traditional diamond market, the professional pengempit still existed, who came from various villages in Martapura and gathered at the market and sat together on halakah. Even though they did not have an official organization, they had been already known as pengempit so the diamond owners did not hesitate to give the diamonds. The diamond owners would not hand over their diamonds to someone who did not know about diamonds because it could be lost or damaged. ${ }^{13}$

Professional pengempit usually took a walk in the market, around the patio, where people sold fish and they avoided unprofessional things. They brought expensive good quality diamonds. They put the diamonds in their pockets. Sometimes,

\footnotetext{
12Interview with Fahmi al Amruzi in Banjarmasin, on July 19th, 2017.

${ }^{13}$ Interview with Fahmi al Amruzi in Banjarmasin, on July 19th, 2017.
} 
they had transactions and unwrapped the diamonds on the side of the gutters, but the diamonds did not disappear or fall into the sewers. This proved that they were so professional that their diamonds did not fall. ${ }^{14}$

After the diamond jewelry stores were present, the general market regulations were applied. At that time, unprofessional pengempit started to take action, people who did not understand diamonds could become pengempit so there was a risk of fraud. It could not be stopped because of its nature of globalization and also because of the low supply of diamonds. ${ }^{15}$

Basically, there were two types of pengempit including long-term-pengempit and short-term-pengempit. The long-termpengempit was pengempit who thought for a long term by maintaining trust. Whereas, the short-term-pengempit was pengempit who only thought about the short term by focusing on profit without thinking about risk. ${ }^{16}$

A persevering pengempit was an istiqamah person. He had a principle that if there was money, there were goods or if there were goods, there was money. The pengempit did not want to give the diamonds if they had

\footnotetext{
14Interview with Fahmi al Amruzi in Banjarmasin, on July 19 ${ }^{\text {th }}, 2017$.

15Interview with Fahmi al Amruzi in Banjarmasin, on July 19 ${ }^{\text {th }}, 2017$.
}

not been paid. For example, if there were people who wanted to pay by reverse check, the goods were delivered after the check was liquid, or if the payment was one week delay, the goods would not be handed over before the money was received. This pengempit wanted to find safety because he could not replace the goods if something happened, most pengempit did not have any financial capital. The pengempit who prioritized safety was working for the long term. He kept the trust until he died. A pengempit like this would never be tempted by large profits even though many people entrusted them to sell the diamonds, but he would not hand over the diamonds to the buyer if he was not paid directly. This kind of pengempit had no problem, he had no debt and could sleep well. ${ }^{17}$

Whereas, a pengempit who only considered about commissions and profits without thinking about the risk. He only thought about profits and did not think about the safety of the diamonds which caused the loss of the diamonds and money, there was only a check and it turned out that the check was empty. Consequently, people would no longer

\footnotetext{
${ }^{16}$ Interview with Abdul Gawi Hasan in Martapura, on June $1^{\text {st }}, 2017$.

${ }^{17}$ Interview with Abdul Gawi Hasan in Martapura, on June 1st, 2017.
} 
trust him, and no one wanted to hand over the diamonds again. ${ }^{18}$

In fact, the exact amount of pengempit in Martapura was still unknown, because they did not have a formal organization. However, people could identify anybody in pengempit network which they usually called as "bubuhan pengempitan".

\section{The Practice of Pengempitan in the}

\section{Islamic Perspective}

The diamond transactions through pengempit can be divided into two groups. The first is pengempit who works as a mediator. He brings the seller to the buyer. If the owner of the diamonds asks pengempit to help to find a buyer or vice versa, the buyer asks for diamonds, then the pengempit will bring him to the diamond owner. This kind of pengempit does not directly involve in the transaction. The transaction is only done by the buyer and the owner. The second type of pengempit works as a representation of the diamond owner. This kind of pengempit will do the transaction directly to the buyer. ${ }^{19}$

The difference between those kinds leads to different types of covenants used in Islam. The covenant for the first group

\footnotetext{
${ }^{18}$ Interview with Abdul Gawi Hasan in Martapura, on June 1 $1^{\text {st }}, 2017$.

${ }^{19}$ Rahmaniah, Dinamika Akad dalam Transaksi Jual Beli Intan di Martapura Kalimantan Selatan, hlm. 61.
}

is called $\ddot{j}$ arah, while the covenant for the second group is called wakalah which is very dependent on the limitations given by the owner if it is limited wakalah, or if it is absolute wakälah, it really depends on local customs. $^{20}$

The Muftis agreed that the mediator in transactions (wasātah tijäriyyah) both dallāl and samsarah was acceptable in Islam because it had been practiced since the time of the Prophet Mohammad based on the hadith narrated by Bukhari. Related to the commissions or profits given to the pengempit can be divided into three provisions. First, the commission is given for $2.5 \%$ of the diamonds selling price. Second, the pengempit gets the profit from the higher selling price than the diamond owner sets. Third, the pengempit gets the profit from the first and second way, both getting commission and profit by selling higher price. $^{21}$

As experienced, the exact amount of payment was given to the pengempit if the diamonds were large; however, if the diamonds were small, the amount would not be determined and it will be given voluntarily. If the diamonds were taken outside Martapura, for example to

\footnotetext{
${ }^{20}$ Rahmaniah, p. 62-63.

${ }^{21}$ Rahmaniah, Dinamika Akad dalam Transaksi Jual Beli Intan di Martapura Kalimantan Selatan, p. 63.
} 
Sulawesi, the commission was $2.5 \%$, and if they were sold only in Martapura, the commission was $1 \%{ }^{22}$ The commission from the owner for the pengempit was ranged from $2 \%$ to $5 \%$ of the selling price, the pengempit could also get a profit by increasing the selling price. For example, if the price of diamonds was IDR 1,000,000, then the pengempit sold it to the buyer for IDR 1,250,000, the narrower got IDR 250,000. The pengempit could also get a commission from the owner based on the agreement, which was usually $2.5 \%$ of the selling price. If the pengempit asked only for a commission of $5 \%$, the pengempit was only a mediator who met the owner and the buyer, and he did not take more profit by increasing the selling price. ${ }^{23}$

In another experience, the commission for the pengempit was either predetermined or not. The amount of commission varied depending on the agreement between the pengempit and the owner, which was done verbally not written. Sometimes, they did not make any agreement at all. It showed that they had already known the standard commission because it had become a habit in society. When they did not make a clear

22Interview with Fahmi al Amruzi in Banjarmasin, on July 19 th $^{\text {th }} 2017$.

23Interview with Abdul Gawi Hasan in Martapura, on June 1st, 2017.

${ }^{24}$ Abdurrahmān bin Șālih al-Ațram, Al-Wasātah at-Tijāriyyah fi al-Mu'āmalāt al-Māliyah, Cet. 2 (Riyād: Dār Isybīliyā, 1997), p. 68. agreement, the customs that exist in the community then applied. This kind of transaction is still appropriate in Islam according to Ibn Sirin, Ata ', Ibrahim, and al-Hasan ${ }^{24}$ The commission received by the mediator must be clear and agreeable to

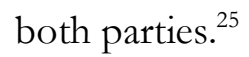

The pengempit only carried diamonds for a day, from morning to afternoon. In the afternoon the diamonds had been returned to the owner. If the diamonds had not returned because the next day someone wanted to check, the pengempit notified the owner that "the diamonds were overnight" (diamonds were not returned for this night), which created a sense of security. If the pengempit took the diamonds out of town, the owner would be told and got a frequent report from the pengempit whenever a prospective buyer gave an offer. Besides that, there was also pengempit who borrowed diamonds from the shop for a week. ${ }^{26}$ Limited time mediators (wasātah) were permitted by the Hanafi

${ }^{25}$ Abdul Azis Dahlan, dkk, ed., Ensiklopedi Hukum Islam, vol. III (Jakarta: Ichtiar Baru van Hoeve, 1996), p. 1624.

${ }^{26}$ Interview with Naimah in Banjarmasin, on June $6^{\text {th }}, 2017$. 
school $^{27}$ and Imam Malik. ${ }^{28}$ Whereas, the Shafi'i school allowed it absolutely. ${ }^{29}$ That kind of transaction in the community of Martapura was in line with the provisions contained in Islam.

When borrowing diamonds from a shop, there were shops that required a deposit and some were not. The deposit was varied. Some shops required a deposit as the cost of diamonds borrowed, and some just required a little amount of money. For example, borrowing two rings, but the deposit was only worth for one ring. The deposit given to the shop would be fully returned after the diamonds were returned. ${ }^{30}$

The muftis of the school agreed on the required deposit to prevent a negligent mediator. ${ }^{31}$ If the mediator was not a negligent person, so he should not be burdened with deposit. This was the opinion of Imam Zufr from the Hanafi School, an opinion of the Maliki school, the Syafi'i school, and also used in the Hanbali school ${ }^{32}$

${ }^{27}$ Syamsuddīn as-Sarakhsi, Al-Mabsūt (Beirut: Dār al-Ma'rifah, tt), p. 215.

${ }^{28}$ Malik bin Anas, Al-Mudawwanah al-Kubra, jilid 11 (Riyād: Kementerian Agama, Wakaf, Dakwah dan Bimbingan, $\mathrm{tt})$, p. 46.

${ }^{29}$ Al-Imām an-Nawāwi, Rauḍatu at-Tālibīn wa 'Umdatu al-Muftīn, Cet. 3 (Beirut: Al-Maktab alIslāmi, 1991), p. 257.

${ }^{30}$ Interview with Naimah in Banjarmasin, on June $6^{\text {th }}, 2017$.
However, according to the opinion of Muhammad and Abu Yusuf from the Hanafi school, a strong opinion within the Maliki school, and the opinion used in the Syafi'i and Hanbali schools was that all mediators must give a deposit. ${ }^{33}$ So, it can be said that the practice is in line with the provisions in Islam, whether the owner of the diamond asks for a deposit or not which depends on the situations and conditions. The trusted pengempit can be free from the deposit, and an unknown pengempit can be asked for the deposit.

In the agreement for kempitan was merely recorded the number of carats of the diamonds, and it was only recorded on the wrapping paper. There was no note for the price, commission, time limit, and others in the wrapping paper. ${ }^{34}$. Sometimes, the diamond owner wrote in their selling notes, and sometimes they did not write at all because they had already memorized everything. ${ }^{35}$

Finally, it could be said that the people of Martapura in the diamond transactions through pengempit did it only verbally. It is

\footnotetext{
31 Ațram, Al-Wasātạh at-Tijāriyyah fi alMu'āmalāt al-Māliyah, p. 267.

${ }^{32}$ Ațram, p. 259.

${ }^{33}$ Atrram, p. 261.

${ }^{34}$ Interview with Fahmi al Amruzi in Banjarmasin, on July 19th, 2017.

${ }^{35}$ Interview with Naimah in Banjarmasin, on June $6^{\text {th }}, 2017$.
} 
still in line with Islamic teachings because according to the muftis the form of siggah in transactions through mediators can be by direct speech, by a gesture, or by writing, whatever can be understood by both parties through the mediator. ${ }^{36}$

\section{Kerakatan and Baparcayaan as a \\ Culture}

Geertz said that behavior was a symbolic action ${ }^{37}$. The symbolic actions in the diamond transactions were reflected in giving commission for the pengempit, giving time limitation for bringing the diamonds, requiring a deposit, and noting. Geertz further mentioned that those kinds of symbolic actions resulted in cultural patterns. A cultural pattern was a series of regular meaningful symbols that were given by humans to the events they experience. ${ }^{38}$ Cultural patterns were models of reality and models for reality. ${ }^{39}$ The model of reality in diamond transactions was the culture of kerakatan and baparcayaan.

36 Ațram, Al-Wasāṭah at-Tijāriyyah fi alMu'āmalāt al-Māliyah, p. 175-179.

${ }^{37}$ Clifford Geertz, The Interpretation of Cultures (New York: Basic Books, Inc., 1973), p. 10.

${ }^{38}$ Geertz, p. 363.

${ }^{39}$ Geertz, p. 93.

${ }^{40}$ Interview with Husaini in Martapura, on may $25^{\text {th }}$, 2017 and interview with Fahmi al Amruzi in Banjarmasin, on July 19th, 2017.

\section{The Religious Meaning of Kerakatan and Baparcayaan}

The culture of kerakatan and baparcayaan could be traced to the teachings of Islam adopted by the people in Martapura and motivated by a strong belief in Islamic teachings (faith in Allah SWT). These cultures had a real influence on people's daily lives. So, the culture of kerakatan and baparcayaan had religious meaning because the behaviors were motivated by religious teachings.

The people's religious knowledge was obtained from religious teachers ${ }^{40}$ and ketariiban at mosques ${ }^{41}$, Aisyizah and Mubammadiyah organizations ${ }^{42}$. According to them, the material obtained from the religious teaching was sufficient for everyday life. They obeyed the teaching and avoided the prohibitions, for example, the prohibitions for lying and cheating. ${ }^{43}$ They thought religion was the main factor for solving all the problems. If the aqidab was strong, the faith was strong, and the surrender was strong, then the person would be safe. It would be different between people who liked religious

\footnotetext{
${ }^{41}$ Interview with Abdul Gawi Hasan in Martapura, on June 1st, 2017.

${ }^{42}$ Interview with Naimah in Banjarmasin, on June $6^{\text {th }}, 2017$.

43Interview with Husaini, Wawancara, 25 Mei 2017, Martapura.
} 
learning and applied it and people who did not. People did not like to go to religious teaching and only think about business would be easy to get risks because they could depend on Allah. ${ }^{44}$

The culture of kerakatan and baparcayaan that influenced the selling process through pengempit at Martapura could not be separated from the beliefs that exist in the society of Martapura. The society of Martapura was religious, they were known as obedient people in practicing Islam, including in buying and selling. They paid attention to the covenant in buying and selling, so they considered a transaction invalid if the covenant was not executed perfectly.

Islamic theory related to kerakatan and baparcayaan is 'așabiyyah and amanah. Following Geertz's theory, 'așabiyyah and amanah can be categorized as models for reality. There are many Islamic theories related to kerakatan which in Islam is called social solidarity ('așabiyyah), for example, the verse about helping each other in AlMaidah (5) verse 2 and the hadith narrated by Muslims about brotherhood. ${ }^{45}$ Moreover, baparcayaan in Islam is called

${ }^{44}$ Interview with Abdul Gawi Hasan in Martapura, on June $1^{\text {st }}, 2017$.

مثل المؤمنين dan المؤمن للمؤمن كالبنيان يثد بعضه بعضا

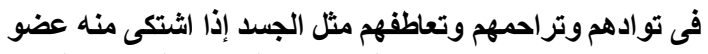

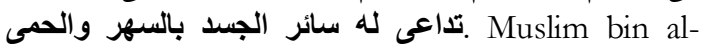
Hajjāj, Șaḥị̣ Muslim, Ed. 1 (Al Riyāḍ: Dār Ṭayyibah, 2006), p. 1201. amanah. Amanah is to give any rights to the owner, not to take anything more than their rights, and not to reduce the rights of others, either in the form of price or commission. ${ }^{46}$ The decree of Allah SW'T related to amanah contained in surah anNisa (4) verse 58 , in surah al-Mu'minun (23) verse 8 , and also in the hadith șahịhain. ${ }^{47}$

\section{The Social Meaning of Kerakatan and Baparcayaan}

The culture of kerakatan made diamond transactions through pengempit existed. Without kerakatan, the pengempit who were mostly from the middle to lower class and did not have strong financial, would be extinct from this business, so the diamond transactions through pengempit would be disappeared from the society in Martapura. Following the theory developed by Ibn Khaldun about 'așabiyyah, kerakatan among bububan pengempitan had the same meaning as' așabiyyah. Ibn Khaldun said that all human beings needed defense and protection, which could not be achieved without a struggle because in humans there

\footnotetext{
46Yusuf Qarḍawi, Dauru al-Qiyāmi wa al-Akhläqi fi alIqtișādi al-Islāmi, translator Zainal Arifin and Dahlia Husin, Norma dan Etika Ekonomi Islam, Ed. 1 (Jakarta: Gema Insani, 1997), p. 177. آية المنافق ثلاث إذا حدث كذب و إذا وعد أخلف و إذا ائتمن خان 47 Șậh Muslim, p. 46.
} 
was a nature of refusal. For this, social solidarity ('așabiyyah) was needed. ${ }^{48}$

Ibn Khaldun mentioned that for most humans, social solidarity was caused by blood ties. Blood ties would lead to true solidarity, if the level of kinship was far then the blood ties would be weaker, but as the substitute, there would be a feeling of familiarity based on a knowledge of brotherhood. Protected friends and people allied with a noble were often in the same relationship with blood relatives, so the protector and the protected person were voluntarily helping out because of the humiliation that raised if the rights of neighbors or relatives or friends were violated. In reality, such a protective bond was just as strong as the blood tie. ${ }^{49}$

If the brotherhood was clear, it would be useful as a natural incentive towards solidarity. However, if it was based solely on the knowledge of ancestors, it would be weak and had little influence on sentiment because it could not trigger the bonds and love caused by social solidarity ('așabiyyah). ${ }^{50}$

Likewise, Yusuf Hidayat's findings in his dissertation stated that there were rules in the interaction among small traders and pengempit in diamond transactions in

${ }^{48} \mathrm{Ibnu}$ Khaldun, Muqaddimah, trans. oleh Ahmadie Thoha, Cet. 12 (Jakarta: Pustaka Firdaus, 2014), p. 151.
Martapura in the form of cooperation and togetherness. These rules were obeyed and used as references spontaneously in their actions. The rules of togetherness among them had a function to maintain their existence because if the rules of togetherness were not developed, they would be extinct along with the scarcity of diamonds ${ }^{51}$. The terms cooperation and togetherness used by Yusuf Hidayat was a representation of kerakatan. So, kerakatan had a social meaning to maintain their existence. The culture of kerakatan made diamond transactions through pengempit still exist. Also, kerakatan was a culture that had been owned by the Banjarese and even by Indonesian. Indonesian were known to have a family culture as the character of Indonesian culture, so it influenced the behavior in all aspects of their lives.

The relationship between the owner and the pengempit was a mutualism relationship. The pengempit who mostly from the middle to lower class and had no enough financial capital needed an owner who trusted him. The owner also really needed the pengempit to sell their diamonds or to get diamonds.

Most pengempit was a person who did not have any diamond, but he had friends or networks about people who usually

\footnotetext{
${ }^{49}$ Khaldun, p. 152.

${ }^{50}$ Khaldun, p. 152.

${ }^{51}$ Hidayat, "Praktik Pedagang Intan," p. 231.
} 
looked for gemstones, so the pengempit would connect the owner with the buyer. The pengempit was usually diligent and eager to know who the owner and the buyer because he wanted to sell it. ${ }^{52}$

Determining the verbal relationship between the owner and the pengempit, there was no written agreement so there would be no data found about an agreement between the owner and the pengempit, even though the value of the diamonds were sometimes very expensive. ${ }^{53}$ Trust in Banjarese was called baparcayaan had become the basis for the relationship between the owner and the pengempit.

Baparcayaan was a culture in the society of Martapura for diamond transactions through pengempit in addition to the culture of kerakatan. Baparcayaan had a social meaning in the mutualism relationship, either among the pengempit or between the pengempit and the diamond owner. Amongst pengempit, they exchanged information both about diamond buyers and about the existence of diamonds. As a result, baparcayaan made diamond transactions through pengempit still existed.

\footnotetext{
52Interview with Abdul Gawi Hasan in Martapura, on June $1^{\text {st }}, 2017$.

53 Interview with Abdul Gawi Hasan in Martapura, on July 26 $6^{\text {th }}, 2013$.
}

\section{The Economics Meaning of Kerakatan and Baparcayaan}

As mentioned previously that kerakatan was one of the cultures in the society of Martapura for diamond transactions through pengempit. The word kerakatan came from the word rakat which means close or can get along. The examples of kerakatan included when one of the pengempit family members died, bububan pengempitan would give contribute to the family member. ${ }^{54}$

Kerakatan among professional pengempit could be seen from the giving of hak mata, a gift from pengempit who successfully sold the diamonds to other pengempit who could not sell the diamonds for helping them bringing a fortune home. Among pengempit also shared information about the diamonds carried and information about the person who was looking for diamonds. ${ }^{55}$

The pengempits habit in helping each other-if there was a misfortune and gave each other when the diamonds were soldas a part of kerakatan culture for economic meaning in increasing fortune. Pengempit who got an unfortunate would get donations, and pengempit whose diamonds had not been sold would also get some

\footnotetext{
${ }^{54}$ Interview with Husaini in Martapura, on May $25^{\text {th }}, 2017$.

55Interview with Fahmi al Amruzi in Banjarmasin, on July 19th, 2017.
} 
money from pengempit whose diamonds had been sold.

The culture of baparcayaan also had an economic meaning in reducing costs for selling. This could be seen from the habit of the diamond owner and the pengempit. They did not make any written agreement in the transaction. Besides, for the trusted pengempit, the diamond owner did not ask for a deposit. This would save some costs because there was no need to make a written agreement and a deposit. In this case, trust became the basis of legal life and the foundation of human legal activities. A rule was not a basis, but trust and relationship were the basis. ${ }^{56}$

This research showed that the behavior of the society in Martapura for their business was not merely for economic purposes. It could be said that in the diamond transaction through pengempit, the religious and social meaning was more dominant than the economic meaning.

This was in line with Ibn Khaldun's thought that the economic aspect was closely related to humanity and survival instinct. The abundant fortune would lead to prosperity. The motivation for working and doing business was not fully oriented

56Satjipto Rahardjo, Hukum dan Perilaku: Hidup Baik adalah Dasar Hukum yang Baik (Jakarta: Penerbit Buku Kompas, 2009), p. 79. to wealth, but also for surviving in social life. However, in capitalism people were no longer care about human values. The most important thing for them was money and resources, even if they had to sacrifice others' rights. ${ }^{57}$

\section{CONCLUSION}

The culture of kerakatan and baparcayaan in diamond transactions through pengempit was a law that lives in society by Islamic teachings that underlined the socioeconomic life of the large Banjar community. The culture of kerakatan and baparcayaan had religious, social, and economic meanings. Kerakatan had a religious meaning called social solidarity or 'asabiyyah. Kerakatan had a social meaning to maintain their existence. Kerakatan had an economic meaning to increase life fortune. Meanwhile, the culture of baparcayaan had a religious meaning called amanah. Moreover, the social meaning of baparcayaan was the mutualism relationship among them. Last, the economic meaning of the culture of baparcayaan was by reducing the costs they spent.

${ }^{57}$ Syarifuddin Jurdi, Awal Mula Sosiologi Modern: Kerangka Epistemologi, Metodologi, dan Perubahan Sosial Perspektif Ibn Khaldun, Cet. 1 (Yogyakarta: Kreasi Wacana, 2012), hlm. 239-240. 


\section{REFERENCES}

Amruzi, Fahmi al. Wawancara, 19 Juli 2017. Martapura.

Anwar, Syamsul. Pemikiran Usul Fikih al Gazaali (450-505/1058-1111). Cet. 1. Yogyakarta: Suara Muhammadiyah, 2015.

Ațram, Abdurrahmān bin Ṣālih al-. AlWasātah at-Tijäriyyah fi al-Mu' àmalät al-Mäliyah. Cet. 2. Riyād: Dār Isybīliyā, 1997.

Aziz, Said. "Potensi Endapan Intan Plaser di Lepas Pantai Kalimantan Selatan dan Barat." http://inaquarter.com, 28 Januari 2010.

Bukhāri, Abū Abdullāh Muhammad bin Ismāīl al-. Sahị al-Bukbāri. Cet. 1. Beirut: Dār Ibni Kas̀īr, 2002.

Dahlan, dkk, Abdul Azis, ed. Ensiklopedi Hukum Islam. Vol. III. Jakarta: Ichtiar Baru van Hoeve, 1996.

Geertz, Clifford. The Interpretation of Cultures. New York: Basic Books, Inc., 1973.

Hadikusuma, Hilman. Pengantar Antropologi Hukum. Cet. 2. Bandung: PT. Citra Aditya Bakti, 2004.

Hasan, Abdul Gawi. Wawancara. Wawancara, 26 Juli 2013. Martapura.

—. Wawancara, 6 Januari 2017. Martapura.

Hidayat, Yusuf. "Praktik Pedagang Intan: Akses dan Pendayagunaan Kapital dalam Perdagangan Intan di Martapura, Kalimantan Selatan." $\mathrm{PhD}$ Thesis, Universitas Gadjah Mada, 2015.

Husaini. Wawancara, 25 Mei 2017. Martapura.

—. Wawancara, 25 Mei 2017. Martapura.

Ideham, dkk. (ed.), M. Suriansyah. Sejarah Banjar. Banjarmasin: Badan Penelitian dan Pengembangan Daerah Propinsi Kalimantan Selatan, 2003.

Jurdi, Syarifuddin. Awal Mula Sosiologi Modern: Kerangka Epistemologi,
Metodologi, dan Perubahan Sosial Perspektif Ibn Khaldun. Cet. 1. Yogyakarta: Kreasi Wacana, 2012.

Khaldun, Ibnu. Muqaddimah. Diterjemahkan oleh Ahmadie Thoha. Cet. 12. Jakarta: Pustaka Firdaus, 2014.

Koentjaraningrat. Sejarah Teori Antropologi II. Jakarta: Penerbit Universitas Indonesia, 2015.

Malik bin Anas. Al-Mudawwanah al-Kubra, jilid 11. Riyād: Kementerian Agama, Wakaf, Dakwah dan Bimbingan, tt.

Muslim bin al-Hajjāj. Sahị Muslim. Cet. 1. Al Riyāọ: Dār Ṭayyibah, 2006.

Naimah. Wawancara, 6 Juni 2017. Martapura.

Nawāwi, Al-Imām an-. Raudatu at-Tălibìn wa 'Umdatu al-Muftin. Cet. 3. Beirut: Al-Maktab al-Islāmi, 1991.

Qardhawi, Yusuf. Norma dan Etika Ekonomi Islam. Diterjemahkan oleh Zainal Arifin dan Dahlia Husin. Cet. 1. Jakarta: Gema Insani, 1997.

Rahardjo, Satjipto. Hukum dan Perilaku: Hidup Baik adalah Dasar Hukum yang Baik. Jakarta: Penerbit Buku Kompas, 2009.

Rahmaniah, Amelia. Dinamika Akad dalam Transaksi Jual Beli Intan di Martapura Kalimantan Selatan. Cet. 1. Yogyakarta: Total Media, 2015.

Sarakhsi, Syamsuddīn as-. Al-Mabsūt. Beirut: Dār al-Ma'rifah, tt.

\section{INTERVIEWS}

Amruzi, Fahmi al., Interview on July $19^{\text {th }}$, 2017. Martapura.

Hasan, Abdul Gawi. Interview on July 26 ${ }^{\text {th }}$, 2013. Martapura.

. Interview on January 6th, 2017. Martapura. Husaini. Interview on May 25th, 2017. Martapura. Naimah. Interview on June 6th, 2017. Martapura 

SYARIAH : Jurnal Hukum dan Pemikiran Volume 20, No.2, Desember 2020 | 123 